\title{
Assessment of palliative patients with chemoresistance pulmonary tuberculosis life quality in the conditions of specialized hospital at the corrective labour colony
}

\author{
0. M. Raznatovska, G. V. Khudyakov \\ Zaporizhzhia State Medical University, Ukraine
}

Key words:

drug-resistant

tuberculosis,

palliative care,

assessment

of quality of life

questionnaire

of the MOS SF-36.

\section{Zaporozhye}

medical journal

2017; 19 (3), 358-362

DOI:

2017.3.100936

E-mail:

raznatovskaya.zp@

mail.ru
10.14739/2310-1210

Objective - to evaluate the quality of life of palliative patients with drug-resistant pulmonary tuberculosis at a specialized hospital penal colony in terms of the questionnaire of the MOS SF-36 and justify the appropriateness of its application for a differentiated approach in dependence of physical or mentally health components oppression, monitoring their health status.

Materials and Methods. Quality of life assessment was performed in 95 patients with drug-resistant pulmonary tuberculosis who were treated in a specialized tuberculosis hospital at the penal colony. 53 patients of them were on palliative treatment and included into main observation group and comparison group consisted of 42 patients who received antimycobacterial chemotherapy in the maintenance phase of treatment. To determine the norms of quality studied indicators in our region, we have formed a control group consisted of 40 healthy volunteers. For quality of life assessment the questionnaire of the MOS SF-36 was used.

Results. Increase the intensity of pain in palliative patients with drug-resistant pulmonary tuberculosis contributes physical functioning limitation. Acute emotional instability (depression, anxiety and negative emotions) with limited social activity causes low self-esteem of mental state. Such changes ultimately result in inhibition of the viability and general health deterioration. For these patients particular attention should be paid to such scale of life quality assessment as PF, VT and MH as they were significantly lower compared with those drug-resistant pulmonary tuberculosis patients with antimycobacterial chemotherapy in maintenance phase of treatment.

Conclusions. Drug-resistant tuberculosis in patients who are in palliative care leads to a drastic reduction of all quality of life parameters. Using the questionnaire of the MOS SF-36 for quality of life in palliative patients with drug-resistant pulmonary tuberculosis assessment is reasonable for a differentiated approach in dependence of physical or mentally health components oppression, health monitoring of these patients.

Ключові слова: хіміорезистентний туберкульоз мегень, паліативне мікування, якість життя, опитувальник MOS SF-36.

Запорізький медичний журнал. - 2017. T. 19, № 3(102). C. 358-362

\section{Оцінювання якості життя паліативних хворих на хіміорезистентний туберкульоз мегень в умовах спеціалізованої мікарні при виправній колонії}

\section{О. М. Разнатовська, Г. В. Худяков}

Мета роботи - оцінити якість життя паліативних хворих на хіміорезистентний туберкульоз легень в умовах спеціалізованої лікарні при виправній колонії за показниками опитувальника MOS SF-36 та обґрунтувати доцільність його застосування для диференційованого підходу надання допомоги залежно від пригнічення фізичного чи психічного компонентів здоров'я, моніторингу стану їхнього здоров'я.

Матеріали та методи. Оцінювання якості життя здійснили у 95 хворих на хіміорезистентний туберкульоз легень, які перебували на лікуванні в умовах спеціалізованої лікарні при виправній колонії. 3 них в основну групу ввійшли 53 особи, які перебували на паліативному лікуванні. Група порівняння - 42 пацієнти, які одержували антимікобактеріальну хіміотерапію в підтримувальну фазу лікування. Для визначення норми досліджуваних показників якості в нашому регіоні створена контрольна група, до якої ввійшли 40 здорових добровольців. Для оцінювання якості життя використовували опитувальник MOS SF-36.

Результати. У паліативних хворих на хіміорезистентний туберкульоз легень наростання інтенсивності болю сприяє обмеженню фізичного функціонування. Різка емоційна нестабільність (депресії, тривоги, негативні емоції) з обмеженням соціальної активності сприяють зниженню самооцінки психічного стану. Такі зміни в підсумку призводять до пригнічення життєздатності та погіршення загального стану здоров'я. Особливої уваги заслуговують у цих хворих такі шкали якості життя, як PF, VT і MH, оскільки вони були вірогідно нижчими порівняно з хворими на хіміорезистентний туберкульоз легень, які отримували антимікобактеріальну хіміотерапію в підтримувальну фазу лікування.

Висновки. У паліативних хворих хіміорезистентний туберкульоз призводить до різкого зниження всіх параметрів якості життя. Використання опитувальника MOS SF-36 для оцінювання якості життя в паліативних хворих на хіміорезистентний туберкульоз легень $€$ доцільним для диференційованого підходу надання допомоги залежно від пригнічення фізичного чи психічного компонентів здоров'я, моніторингу стану здоров'я цих пацієнтів.

\section{Ключевые слова:} химиорезистентный туберкулёз лёгких, памлиативное мечение, качество жизни, опросник MOS SF-36.

\section{Оценка качества жизни памиативных больных химиорезистентным туберкулёзом лёгких в условиях специализированной больницы при исправительной колонии}

\section{Е. Н. Разнатовская, Г. В. Худяков}

Цель работы - оценить качество жизни паллиативных больных химиорезистентным туберкулёзом лёгких в условиях специализированной больницы исправительной колонии по показателям опросника MOS SF-36 и обосновать 
целесообразность его применения для дифференцированного подхода оказания помощи в зависимости от угнетения физического или психического компонентов здоровья, мониторинга состояния их здоровья.

Материалы и методы. Оценку качества жизни провели у 95 больных химиорезистентным туберкулёзом лёгких, которые находились на лечении в условиях специализированной больницы при исправительной колонии. Из них в основную группу вошли 53 больных, которые находились на паллиативном лечении, и в группу сравнения - 42 больных, которые получали антимикобактериальную химиотерапию в поддерживающей фразе лечения. Для определения нормы исследуемых показателей качества в нашем регионе была создана контрольная группа, в которую вошли 40 здоровых добровольцев. Для оценки качества жизни использовали опросник MOS SF-36.

Результаты. У паллиативных больных химиорезистентным туберкулёзом лёгких нарастание интенсивности боли способствует ограничению физического функционирования. Резкая эмоциональная нестабильность (депрессия, тревога и негативные эмоции) с ограничением социальной активности способствуют снижению самооценки психического состояния. Такие изменения в итоге приводят к угнетению жизнеспособности и ухудшению общего состояния здоровья. Особого внимания заслуживают у этих больных такие шкалы качества жизни, как PF, VT и MH, поскольку они были достоверно ниже по сравнению с больными химиорезистентным туберкулёзом лёгких, получавшими антимикобактериальную химиотерапию в поддерживающую фазу лечения.

Выводы. У паллиативных больных химиорезистентный туберкулёз ведёт к резкому снижению всех параметров качества жизни. Использование опросника MOS SF-36 для оценки качества жизни у паллиативных больных химиорезистентным туберкулёзом лёгких целесообразно для дифференцированного подхода оказания помощи в зависимости от угнетения физического или психического компонентов здоровья, мониторинга состояния здоровья этих пациентов.

Introduction. For today, according to the World Health Organization (WHO), Ukraine is included into the list of 30 countries with the worst situation of chemoresistance pulmonary tuberculosis (CRTB) [14]. In 2016, according to the Global report of WHO, efficiency of patients with multiresistant tuberculosis (MRTB) treatment in Ukraine made $39 \%$.

Pulmonary CRTB belongs to clinical states when patients can need palliative care as antituberculous medicines (ATM) can not provide adequate treatment, and other clinical and social conditions make treatment of patient impossible [1]. Delivery of health care to palliative patients, including patients with pulmonary CRTB, is, first of all, in promoting improvement patients quality of life $(\mathrm{QL})$ in process of disease progression and its rising to the terminal stage through the prevention and relief of patient suffering by early diagnosis and decrease of disease symptoms [2-4]. QL is an integrated indicator of the general human welfare [5].

In the different countries assessment of $Q L$ of TB patients is carried out by means of various questionnaires which have the criteria and rating scales [6-9]: a questionnaire of $Q L$ of WHO ( $Q$ of $Q L$ of WHO), a questionnaire of $\mathrm{QL}$ assessment of the European group of studying of $\mathrm{QL}$ (EUROQOL - EuroQOL Group), the Nottingham profile of health (Nottingham Health Profile), the generalized scale of QL assessment (Overall Quality of Life Scale), etc.

Researchers of the International Centre of $Q L$ research (ICR of QL, St. Petersburg, RF) (1998) [14] created the Russian-language version of a questionnaire of Medical Outcomes Study-Short Form (MOS) SF-36 (the author is J. E. Ware, 1992 [15]) [10]. This version of a questionnaire of the MOS SF-36 is accepted for carrying out of QL population researches. It is recommended to use a questionnaire of the MOS SF-36 for QL assessment of healthy persons and at various diseases including at tuberculosis [11-13].

For today QL of TB patients is enough studied by means of questionnaires, both in an active phase, and with residual changes after tuberculosis. However, there are no data of $Q L$ research in palliative patients with pulmonary CRTB that is important for the differentiated approach of treatment and care, the warning of tuberculosis complications development, monitoring of these patients health state. The above makes the chosen subject urgent.
The purpose of the work is to estimate the quality of life of palliative patients with drug-resistant pulmonary tuberculosis in a specialized hospital penal colony in terms of the MOS SF-36 questionnaire and justify the appropriateness of its application for a differentiated approach in dependence of physical or mentally health components oppression, monitoring their health condition.

\section{Materials and Methods}

Assessment of QL was carried out among 95 patients with pulmonary CRTB who were on treatment in specialized hospital at Public Institution "Sofiyivka corrective labour colony (No. 55)" of the Ministry of Justice of Ukraine in the Zaporizhzhia region. There were 53 patients on palliative treatment in the main group and 42 patients in group of comparison received ATM in the supportive phase of chemotherapy.

There were no incurable patients among the palliative patients with CRTB (group 1). The most part of this group consisted of patients who did not require treatment.

To determine the norms of quality studied indicators in our region, we have formed a control group consisted of 40 healthy volunteers. All 3 groups of study subjects were males $(100 \%)$ as corrective labour colony was for men. Average age of healthy volunteers was $(38.9 \pm 6.1)$, average age of patients of the main group was $(35.0 \pm 1.1)$ and average age of comparison group was $(36.3 \pm 2.3)$.

For QL assessment a questionnaire of the MOS SF-36 (ICR of QL, St. Petersburg, 1998) was used. There were estimated 8 scales according to the questionnaire of the MOS SF-36: Physical Functioning (PF) - physical functioning; Role-Physical (RP) - Influence of a physical state on role functioning; Bodily Pain (BP) - intensity of pain and its influence on ability to be engaged in daily activity; General Health $(\mathrm{GH})$ - the general state of health; Vitality (VT) - viability; Social Functioning (SF) - social functioning; Role-Emotional (RE) - influence of an emotional state on role functioning; Mental Health (MH) - a self-assessment of mental health.

Authors of a questionnaire of the MOS SF-36 recommended to carry out an assessment of a physical component of health in a complex according to 1-4 scales (PF, RP, BP,
Запорожский медицинский журнал. - 2017. T. 19, № 3(102). C. $358-362$ 
Table 1. Assessment of a physical component of health according to scales of questionnaire of the MOS SF-36 (M \pm SD)

\begin{tabular}{lllllll}
\hline Indicator & $\begin{array}{l}\text { Control } \\
(\mathbf{n}=\mathbf{4 0})\end{array}$ & $\begin{array}{l}\text { Main group } \\
(\mathbf{n}=53)\end{array}$ & $\begin{array}{l}\text { Comparative } \\
\text { group }(\mathbf{n}=\mathbf{4 2})\end{array}$ & $\mathbf{P}_{2-1}$ & $\mathbf{P}_{3-1}$ & $\mathbf{P}_{2-3}$ \\
\hline PF & $90.6 \pm 0.7$ & $58.1 \pm 2.4$ & $63.6 \pm 2.7$ & $<0.05$ & $<0.05$ & $>0.05$ \\
RP & $88.4 \pm 2.3$ & $20.8 \pm 3.3$ & $56.5 \pm 3.2$ & $<0.05$ & $<0.05$ & $<0.05$ \\
BP & $86.1 \pm 2.2$ & $49.1 \pm 2.3$ & $59.1 \pm 2.9$ & $<0.05$ & $<0.05$ & $>0.05$ \\
GH & $74.6 \pm 0.9$ & $46.4 \pm 2.2$ & $53.7 \pm 2.6$ & $<0.05$ & $<0.05$ & $>0.05$ \\
$\begin{array}{l}\text { Physical component } \\
\text { of health, points }\end{array}$ & $85.0 \pm 0.9$ & $43.6 \pm 1.7$ & $58.2 \pm 1.5$ & $<0.05$ & $<0.05$ & $<0.05$ \\
\hline
\end{tabular}

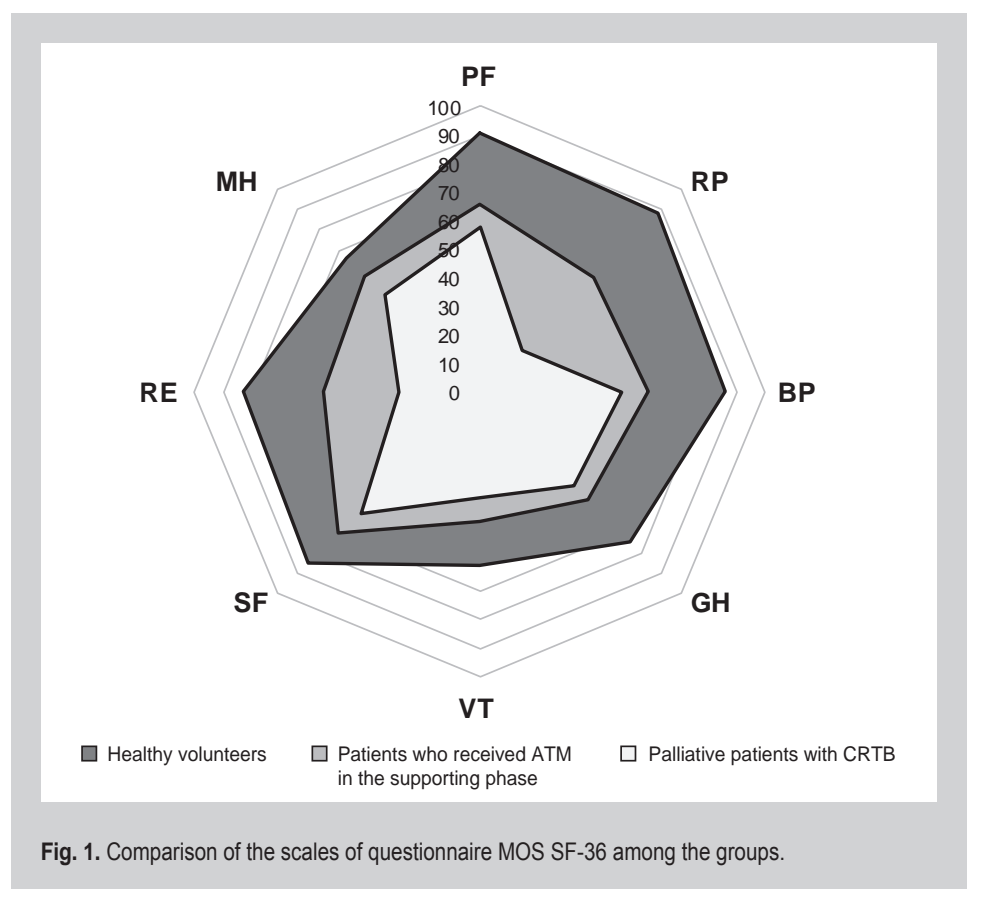

$\mathrm{GH})$, and a mental component of health - according to 5-8 scales (VT, SF, RE, MH).

Results of the study were processed by the modern methods of the analysis on the personal computer with statistical packet of the license program STATISTICA® for Windows 6.0 (Stat Soft Inc., No. AXXR712 D833214FAN5). Normality of distribution of the quantitative signs was analyzed by Shapiro-Wilkie's test. Parameters had normal distribution and were presented in the form of an arithmetic average and a standard deviation $(\mathrm{M} \pm \mathrm{SD})$. Comparison of indices in groups was made using Student's t-test. Statistically significant considered a difference according to $p<0.05$. All tests were double-sided. For the purpose of correlations between scales of questionnaire of the MOS SF-36 in palliative pulmonary CRTB detection, correlation analysis was carried out by calculation of grade correlation coefficients between the quantitative signs - Pearson's $r$.

\section{Results and Discussion}

Assessment of questionnaires results according to health physical component scales (Table 1, Fig. 1) showed that at patients with pulmonary CRTB both palliative and who received ATM in the supportive phase indicators according to all 4 scales were $(p<0.05)$ much lower in comparison with scales of healthy volunteers. In general the scale of physical violations role in restriction of palliative patients activity was 1,9 times less in comparison with the scale of healthy volunteers $(43.6 \pm 1.7$ against $85.0 \pm 0.9 ; p<0.05)$ and 1.3 times less in comparison with the patients receiving ATM in the supportive phase $(43.6 \pm 1.7$ against $58.2 \pm 1.5 ; p<0.05)$ that testified about more expressed restriction of daily activity at these persons under the influence of main disease without antimycobacterial treatment. Assessment of physical state influence on role functioning (RP) scale paid attention to 2.7 times less in palliative patients with pulmonary CRTB, than in patients receiving ATM in the supportive phase $(20.8 \pm 3.3$ against $56.5 \pm 3.2 ; p<0.05$ ).

The analysis of interrelations between scales of health physical component in patients with pulmonary CRTB was carried out. It has been established that decrease of the BP scale was directly connected with decrease of the PF scale $(r=0.401 ; p<0.01)$ that directly influenced considerable decrease of the GH scale $(r=0.324 ; p<0.05)$. And in patients with pulmonary CRTB received ATM in the supportive phase only direct link between decrease of the RP and PF scales $(r=0.410 ; p<0.01)$ was defined.

Thus, increase of pain intensity among palliative patients with pulmonary CRTB promoted restriction of physical functioning, and as a result, disorders of health general state. While patients with pulmonary CRTB received ATM in the supportive phase had only physical state influence on role and physical functioning.

Assessment of health mental component (Table 2, Fig. 1) has established that it was similar to physical component scales in patients with pulmonary CRTB, regardless of treatment type, indicators of all 4 scales were $(p<0.05)$ much lower in comparison with scales of healthy volunteers. But there were 2 important moments in palliative patients with pulmonary CRTB. Firstly, the scale of emotional functioning $(\mathrm{RE})$ in these patients was clearly lowered to $(28.9 \pm 3.1)$ of standard units, that was 2.8 times less, than healthy volunteers $(p<0.05)$ and 1.9 times less, than in persons of the 2 group $(p<0.05)$. Secondly, limitations of social contacts were defined in comparison with healthy volunteers and patients of the 2 group (1.4 and 1.2 times respectively; $p<0.05$ ). In general the expressed changes of mental health scale were defined among palliative patients, that was shown by its decrease 1.7 times in comparison with the scale of healthy volunteers $(43.4 \pm 1.8$ against $73.8 \pm 1.3 ; p<0.05)$ and 1.3 times in comparison with the patients received ATM in the supportive phase $(43.4 \pm 1.8$ against $56.9 \pm 1.4 ;(p<0.05)$.

According to the analysis of correlations between scales of health physical component, lowering of the RE scale in palliative patients directly influenced lowering of the SF scale $(r=0.318 ; p<0.05)$, lowering of the $\mathrm{MH}$ scale had a direct link with lowering of the SF $(r=0.396 ; p<0.01)$ and VT $(r=0.596$; $p<0.001)$ scales. While in patients with pulmonary CRTB received ATM in the supportive phase there was defined only a direct link between lowering of the MH and VT scales $(r=0.491 ; p<0.001)$.

Thus, sharp emotional instability (depressions, mental tension and negative emotions) and restrictions of social activity of palliative patients with pulmonary CRTB promoted lowering of mental status self-assessment, and as a result, viability oppression. But patients with pulmonary CRTB received ATM in the supportive phase had only influence of mental status self-assessment lowering on viability suppression. 
The average value of $Q \mathrm{~L}$ according to questionnaire of the MOS SF-36 scales (Fig. 2) in patients with pulmonary CRTB, regardless of a treatment type, was lower in comparison with the index of healthy volunteers: in the main group 1.8 times $(43.5 \pm 1.5$ against $79.4 \pm 0.9 ; p<0.05)$ and in the group of comparison 1.4 times $(56.7 \pm 1.3$ against $79.4 \pm 0.9$; $\mathrm{p}<0.05)$. However, palliative patients with pulmonary CRTB had it 1.3 times lower, than the patients received ATM in the supportive phase $(p<0.05)$ that was referred to sharp decrease of life quality in patients with pulmonary CRTB who didn't receive antimycobacterial therapy.

\section{Conclusions}

1. Palliative patients with chemoresistance pulmonary tuberculosis quality of life significantly decreased by all parameters: physical functioning, physical status influence on role functioning, intensity of pain and its influence on ability to be involved in daily activities, general state of health, viability, social functioning, emotional status influence on role functioning, mental health self-assessment.

2. Increase of palliative patients with CRTB pain intensity promoted reduction of physical functioning and pronounced emotional instability (depressions, mental tensions and negative emotions), with restriction of social activity it promoted lowering of mental status self-assessment and as a result led to oppression of viability and general health problems.

3. Special attention should be given to patients who had significantly lower indices according to PF, VT and MN scales of life quality in comparison with patients with pulmonary CRTB received ATM in the supportive phase.

4. Use of the MOS SF-36 questionnaire for QL assessment among palliative patients with pulmonary CRTB is expedient for differentiated approach of assistance depending on oppression of health physical or mental components and monitoring of these patients health condition.

Perspectives of further scientific research. Further study of palliative patients with pulmonary CRTB quality of life according to scales of the MOS SF-36 questionnaire in conditions of specialized hospital of corrective labour colony in the course of revealed violations correction, general observation and monitoring.

\section{References}

[1] Ukraina. MOZ. (2014). Unifikovanyi klinichnyi protokol pervynnoi, vtorynnoi (spetsializovanoi) ta tretynnoi (vysokospetsializovanoi) medychnoi dopomohy doroslym «Tuberkuloz». [Unified clinical protocols of primary, secondary (specialized) and tertiary (highly specialized) medical care for adults «Tuberculosis»]. [in Ukrainian].

[2] Davies, E., \& Higginson, I. J. (Eds.) (2005). Palliativnaya pomoshh' [Palliative care]. [in Russian].

[3] YeAPD. (2013). Prazka xartiia «Otrymannia paliatyvnoi dopomohy - pravo liudyny». [Prague Charter "Getting palliative care - a human right»]. Retrieved from: http://eapcspeaksrussian. eu.aspx. [in Ukrainian].

[4] YeAPD. (2011). Bila knyha standartiv z paliatyvnoi dopomohy. Rekomendatsii Yevropeiskoi Asotsiatsii paliatyvnoi dopomohy [White Paper on standards and norms for hospice and palliative care in Europe. Recommendation of the European Association of Palliative Care]. Retrieved from: http://ligalife.com.ua/2011/paliativna/standart/ 4parent-kontekstta-metodologiyal. [in Ukrainian].

[5] Novik, A. A., \& Ionova, T. I. (2007) Rukovodstvo po issledovaniju kachestva zhizni $v$ medicine [Guide to the study of quality of life in medicine]. Moscov: OLMAPRESS [in Russian].

[6] Motrich, I. V. (2008). Kharakterystyka yakosti zhyttia studentiv, khvorykh na vpershe vyiavlenyi tuberkuloz leheniv [Quality of life characteris-
Table 2. Assessment of mental component of health according to scales of the MOS SF-36 questionnaire $(\mathrm{M} \pm \mathrm{SD})$

\begin{tabular}{lllllll}
\hline Indicator & $\begin{array}{l}\text { Control } \\
(\mathbf{n}=\mathbf{4 0})\end{array}$ & $\begin{array}{l}\text { Main group } \\
(\mathbf{n}=53)\end{array}$ & $\begin{array}{l}\text { Comparative } \\
\text { group }(\mathbf{n}=\mathbf{4 2})\end{array}$ & $\mathbf{P}_{2-1}$ & $\mathbf{P}_{3-1}$ & $\mathbf{P}_{2-3}$ \\
\hline VT & $61.0 \pm 1.2$ & $37.0 \pm 2.9$ & $45.6 \pm 3.0$ & $<0.05$ & $<0.05$ & $>0.05$ \\
SF & $85.1 \pm 2.5$ & $59.7 \pm 2.2$ & $70.2 \pm 2.4$ & $<0.05$ & $<0.05$ & $<0.05$ \\
RE & $82.9 \pm 2.5$ & $28.9 \pm 3.1$ & $54.8 \pm 2.5$ & $<0.05$ & $<0.05$ & $<0.05$ \\
MH & $66.1 \pm 1.3$ & $47.8 \pm 2.4$ & $57.1 \pm 2.8$ & $<0.05$ & $<0.05$ & $>0.05$ \\
Psychological component & $73.8 \pm 1.3$ & $43.4 \pm 1.8$ & $56.9 \pm 1.4$ & $<0.05$ & $<0.05$ & $<0.05$ \\
of the health, points & & & & & & \\
\hline
\end{tabular}

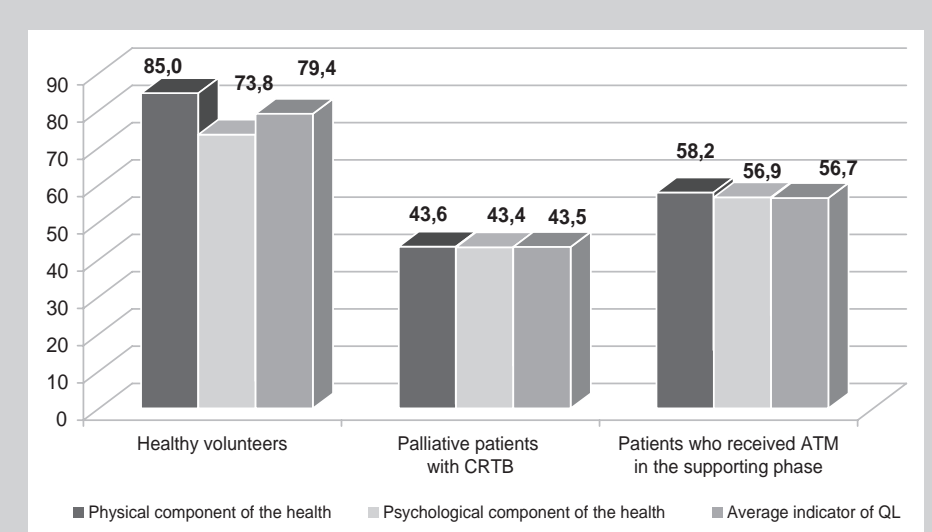

Fig. 2. Average values of $Q L$ according to questionnaire of the MOS SF-36 scales among patients with pulmonary CRTB, standard units.

tics in students with newly diagnosed lung tuberculosis]. Ukrainskyi pulmonolohichnyi zhurnal, 2, 68-70. [in Ukrainian].

[7] Aniskina, E. A., Makarova, I. I., Strakhov, K. A., \& Al-Daud, S. D. (2012). Issledovanie kachestva zhizni bol'nykh tuberkulyozom legkikh [Study of quality of life of patients with pulmonary tuberculosis]. E'kologiya cheloveka, 4, 58-62. [in Russian].

[8] Tsapenko, Y. P., Boiko, M. G., Kraevska, O. O., Alieva, N. M., \& Krasnoshapka, Y. O. (2012). Porivnialna kharakterystyka yakosti zhyttia ta stanu zdorov'ia khvorykh infiltratyvnym tuberkulozom lehen $v$ dynamitsi na riznykh etapakh medychnoi reabilitatsii [Comparative characteristics of life quality and health condition in patients with infiltrative tuberculosis of lungs in dynamics during different stages of medical rehabilitation]. Svit biolohii ta medytsyny, 3, 112-115. [in Ukrainian].

[9] Chushkin, M. I., Smerdin, S. V., Ots, O. N., \& Mandrykin, S. Yu. (2016). Sravnitel'nyj analiz anket dlya ocenki kachestva zhizni bol'nykh tuberkulyozom legkikh $v$ processe provodimogo lecheniya [The comparative analysis of questionnaires of evaluation of life quality of patients with tuberculosis of lungs in process of applied treatment]. Zdravoohranenie Rossijskoj Federacii, 3(60), 133-137. [in Russian].

[10] Internet-sajt MCY'KZh. [Website MTSIKZH]. Retrieved from http://www. mcqlr.da.ru. [in Russian].

[11] Chushkin, M. I., Belevskij, A. S., Meshheryakova, N. N., \& Yarcev, S. S. (2009). Ispol'zovanie ankety SF-36 dlya ocenki kachestva zhizni lic, izlechennykh ot tuberkuleza legkikh [Using the SF-36 questionnaire to assess quality of life of persons cured of pulmonary tuberculosis]. Pul'monologiya, 6, 87-89. [in Russian].

[12] Velikaya, O. V., \& Akulova, A. V. (2015). Ocenka kachestva zhizni zhenshhin, bol'nykh tuberkulyozom legkikh, $s$ ispol'zovaniem ankety SF-36 [Evaluation of the quality of life of women, patients with pulmonary tuberculosis, using the SF-36 questionnaire]. Nauchnye vedomosti. Seriya Medicina. Farmaciya, 16(213), 31, 110-115. [in Russian].

[13] Molchanova, L. F., \& Volkova, E. N. (2011). Kachestvo zhizni bol'nykh tuberkulezom kak kriterij e'ffektivnosti lecheniya [Quality of life in patients with tuberculosis as a criterion of efficiency treatment]. Sovremennye problemy nauki i obrazovaniya vypusk, 6, 1-6. [in Russian].

[14] WHO. (2015). Global Tuberculosis Report 2015. Retrieved from http:// apps.who.int/iris/bitstream/10665/191102/1/9789241565059_eng.pdf.

[15] Ware, J. E., \& Sherbourne, C. D. (1992). The MOS 36-Item Short-Form Health Survey. Med. Care, 30(6), 473-483. 
Information about authors:

Raznatovska O. M., MD, PhD, DSci, Associate Professor, Professor,

Department of Phthisiology and Pulmonology, Zaporizhzhia State

Medical University, Ukraine.

Khudyakov G. V., MD, Post-graduate student, Department

of Phthisiology and Pulmonology, Zaporizhzhia State Medical

University, Ukraine.

\section{Відомості про авторів:}

Разнатовська О. М., А-р меА. наук, Аоцент, професор

каф. фтизіатрії та пульмонології, Запорізький Аержавний

медичний університет, Україна.

Худяков Г. В., аспірант каф. фтизіатрії та пульмонології,

Запорізький державний медичний університет, Україна.

\section{Сведения об авторах:}

Разнатовская Е. Н., А-р меА. наук, Аоцент, профессор каф. фтизиатрии и пульмонологии, Запорожский

госуАарственный меАицинский университет, Украина.

ХуАяков Г. В., аспирант каф. фтизиатрии и пульмонологии,

Запорожский госуАарственный меАицинский университет,

Украина.

Конфмікт інтересів: віАсутній.

Conflicts of Interest: authors have no conflict of interest to declare.

Надійшло Ао реАакції / Received: 20.02.2017

Після Аоопрацювання / Revised: 13.03.2017

Прийнято АО Аруку / Accepted: 31.03.2017 